\title{
The Prevalence of Alternative-complementary Therapies in Patients with Multiple Sclerosis
} Multipl Skleroz Hastalarında Alternatif ve Tamamlayıcı Tedavilerin Kullanım Sıklı̆̆ı

 \\ (1) Mesude Tütüncü, (1) Aysun Soysal
}

Istanbul Bakirkoy Prof. Dr. Mazhar Osman Mental Health and Nerve Diseases Training and Research Hospital, Clinic of Neurology, Istanbul, Turkey

\begin{abstract}
Objective: Multiple sclerosis (MS) is a chronic demyelinating/degenerative disease of the central nervous system that causes disability in young adults. Complementary medicine (CM) and alternative medicine (AM) as a concept is outside the scope of traditional medicine and generally includes all diagnostic and treatment methods for which scientific data are insufficient. Facilitating access to alternative-complementary therapies makes their use widespread. The aim of this study was to evaluate the knowledge level of patients with MS by using a questionnaire and the knowledge of the perception of AM.

Materials and Methods: Patients who were definitively diagnosed as having MS-clinically isolated syndrome in the clinic of our hospital were included on a voluntary basis. Sociodemographic characteristics, type of MS, date of diagnosis, number of attacks, and MS disability scale were recorded. The questionnaire, which was prepared for alternative or complementary therapies used, was completed by the same researcher. Data were analysed using SPSS 21 program.

Results: Two hundred ten patients with MS were included in our study. It was determined that all patients were aware of AM/CM treatments, the highest rate of information was obtained from the internet (76\%), 1.4\% AM, $49 \% \mathrm{CM}$ was used. Ninety-seven \% of the patients received TT for the purpose of relieving their symptoms $(\mathrm{p} \leq 0.005)$. Mostly garlic (83.4\%), caper (79.6\%), ginger $(69.9 \%)$, and goat's milk $(60 \%)$ was used. CM was statistically significantly higher in the first decade $(\mathrm{p} \leq 0.005)$. It was observed that $32 \%$ of the patients used TT after the $2^{\text {nd }} \mathrm{MS}$ attack without any significance.

Conclusion: Our study showed that patients with MS used CM temporarily and with high rates. In contrast to the literature, the rate of use in the first period of the disease was found to be significantly higher. This condition was interpreted as the fact that at the beginning of the disease it could be made with the hope of fighting MS and fully recovering, but after the understanding of the nature of the disease, the use of AM/CM decreased.
\end{abstract}

Keywords: Multiple sclerosis treatment, alternative medicine, complementary medicine

Öz

Amaç: Multipl skleroz (MS) genç yetişkinlerde özürlülüğe neden santral sinir sisteminin kronik demiyelinizan/dejeneratif hastalı̆̆ıdır. Tamamlayıcı ve alternatif tıp, geleneksel tıbbın kapsamı dışında kalan ve genellikle hakkında bilimsel verinin yetersiz olduğu tüm teşhis ve tedavi yöntemlerini içeren bir kavramdır. Alternatif-tamamlayıcı tedavilere ulaşımın kolaylaşması kullanımlarını yaygınlaştırmaktadır. Biz bu çalışmada MS tanısı alan hastalarımızın tamamlayıcı tıbbı (TT) ve alternatif tıbbı (AT) kullanma oranlarını, bu tedaviler konusundaki bilgi düzeylerini, kullananlara ilişkin verileri bir anket çalışması ile değerlendirilmesini amaçlandık.

Gereç ve Yöntem: Hastanemiz MS polikliniğinde kesin MS-klinik izole sendrom tanısı alan hastalar gönüllülük esasına göre çalışmaya dahil edildi. Sosyodemografik özellikler, MS tipi, tanı tarihi, yıllık atak sayısı, MS özürlülük skalası hazırlanan forma kaydedildi. Kullanılan alternatif ya da tamamlayıcı tedaviler için düzenlenen soru formu yüzyüze görüşülerek aynı araştırmacı tarafından dolduruldu. Veriler, SPSS 21 programı kullanılarak analiz edildi.

Bulgular: İki yüz on MS'linin katıldığg çalışmamızda, hastaların hepsinin AT/TT tedavilerinden haberdar oldukları, bilgiyi en yüksek oranda internetten sağladıkları (\%76), \%1,4 oranında AT, \%49 oranında bir veya daha fazla TT kullandıkları saptandı. Hastaların \%97'si TT'yi semptomlarını gidermek amacıyla almıslardı $(\mathrm{p} \leq 0,005)$. TT olarak en fazla sarımsak $(\% 83,4)$, kapari $(\% 79,6)$, zencefil $(\% 69,9)$, keçisütü $(\% 60,1)$ kullanılmışt1. TT'yi almaları istatistiksel olarak anlamlı olarak ilk on yıl içinde fazla idi $(\mathrm{p} \leq 0,005)$. İstatistiksel anlamlılı̆̆a ulaşmamakla beraber hastaların \%32'sinin TT’yi 2. MS atağından sonra kullandıkları gözlemlendi.

Address for Correspondence/Yazıșma Adresi: Rabia Gökçen Gözübatık Ceelik MD, Istanbul Bakirkoy Prof. Dr. Mazhar Osman Mental Health and Nerve Diseases Training and Research Hospital, Clinic of Neurology, Istanbul, Turkey

Phone: +90 5549370087 E-mail: gokcen3@hotmail.com ORCID: orcid.org/0000-0002-8186-8703

Received/Geliş Tarihi: 28.12.2018 Accepted/Kabul Tarihi: 27.03.2019

${ }^{\circ}$ Copyright 2019 by Turkish Neurological Society

Turkish Journal of Neurology published by Galenos Publishing House. 


\section{Öz}

Sonuç: Çalışmamız, hastalarımızın yüksek oranda ancak geçici süreyle tamamlayıcı tedavileri kullandıklarını göstermektedir. Literatürlerden farklı olarak hastalığın ilk dönemlerinde kullanım oranı anlamlı yüksek bulunmuştur. Bu durum hastalığın başında MS’le savaşma ve tamamen iyileşme umuduyla yapılmış olabileceği ancak zaman geçtikçe hastalığın doğasının anlaşılması sonrası AT/TT kullanımının azaldı $\breve{g} 1$ şeklinde yorumlanmıştır.

Anahtar Kelimeler: Multipl skleroz tedavisi, alternatif tedavi, tamamlayıcı tedavi

\section{Introduction}

Multiple sclerosis (MS) is an autoimmune central nervous system disease characterized by inflammation, demyelination, and axonal damage (1). The disease often occurs in young adults and is the most important cause of disability after traffic accidents in young people. With increasing age with the disease, sometimes the frequency and severity of symptoms such as muscle weakness, sensory disorders, spasticity, tremor, seizures, and sphincter and sexual dysfunction increases and it is difficult to obtain a response to medical treatments $(2,3,4)$. In MS, as in other chronic diseases, symptoms increase as the duration of the disease lengthens, and the continuity of treatment, failure to obtain the desired or expected response by patients to treatment, and various sociocultural pressures lead people to apply complementary and/or alternative treatment methods.

Complementary and alternative medicine (AM) is a concept that involves all diagnostic and treatment methods outwith the scope of medical treatment, for which there are insufficient scientific data. AM is defined as "any kind of health care that is used in place of medical treatments, but which are not considered as treatment by modern medicine." Patients use AM by rejecting the medical treatments they need to receive in the belief that they will be cured. Complementary medicine (CM) comprises herbal products and physical activities that are applied by physicians in order to improve the quality of life of patients, reduce symptoms and adverse effects of drugs, provide physical and psychological support, along with the classic medical treatment recommended to them $(5,6,7,8,9)$.

In the literature, it is known that the $\mathrm{AM} / \mathrm{CM}$ use of patients with $\mathrm{MS}$ is common and that $\mathrm{AM} / \mathrm{CM}$ use rates and variety vary from country to country and region to region. AM/CM use rates were observed as 60-67\% in Canada and America, 35$67 \%$ in Denmark, Spain and Germany, and 25-42\% in Turkey $(2,3,4,5,6,7,8,9,10,11)$. Boz (7) reported in an article on the frequency of use of AM/CM in MS in the Eastern Black Sea region in 2010 that the rate of religious faith-based treatments such as amulet, lead pouring, and being prayed for by a religious leader was $5.4 \%$, the rate of using thermal springs was $6.4 \%$, the rate of using massage, exercise and physiotherapy was $6.5 \%$, the rate of ozone therapy was $2.1 \%$, and the rate of diet-related treatment was $3.3 \%$. In the same article, most patients stated that they used these treatments to reduce symptoms related to MS, and to make themselves feel better spiritually and physically, rather than for treating MS, and that they often learned about these treatments from friends or the internet (7).

To know the rate and perception of the choice of CM and AM that can be used by patients as an additional or alternative to their current treatment, and to have knowledge about this issue will increase the confidence of physicians and will play a positive role in the relationship between the patient and physician. Therefore, in our study, we aimed to investigate the knowledge levels, sources of information, and causes of use of $\mathrm{AM} / \mathrm{CM}$, and their relationship with sociodemographic features and disease characteristics of our patients in the MS outpatient of our clinic.

\section{Materials and Methods}

Two hundred ten patients with MS or clinically isolated syndrome (CIS) were included in the study on a voluntary basis between June 2018 and November 2018 at Bakırkoy Mental and Nervous System Diseases Training and Research Hospital, Multiple Sclerosis Outpatient Clinic. Sociodemographic features, type of MS, date of diagnosis of MS, number of annual attacks, MS disability scale [Expanded Disability Status Scale (EDSS)], and income level were recorded in a form. The use of $\mathrm{AM} / \mathrm{CM}$ was evaluated through a multiple-choice questionnaire including data such as alternative or complementary treatments used, cause of use, how the patients reached the AM/CM method or who recommended the method, the duration of use, which symptoms were improved/worsened by the AM/CM method, and whether patients developed an attack while using an AM/CM method. The questionnaire was applied in the same conditions, in the same environment, and by the same researcher. The data of the research were analyzed using the SPSS 21 package program. The chi-square test was used in the intergroup comparison of categorical measurements. In all tests, the level of statistical significance was accepted as 0.05 .

Prior to the application of the research, approval was obtained from the ethics committee of Istanbul Bakirkoy Prof. Dr. Mazhar Osman Mental Health and Nerve Diseases Training and Research Hospital (Decision no: 204). Written consent was obtained from all participants.

\section{Results}

A total of 210 patients with MS, 132 of whom were female, were included in the study. The mean age of the patients was $42 \pm 5.5$ (range, 19-69 years). Of the patients, $4.2 \%$ had CIS, 79\% had relapsing remitting MS, $13.3 \%$ had secondary progressive MS, and 3.3\% had primary progressive MS. No association was observed between AM/CM use and MS type. The mean EDSS was $3.4 \pm 2.1$. There was also no association between disability and AM/ $\mathrm{CM}$ use that reached the level of significance.

Of our patients, $66.6 \%$ were educated for less than 11 years and did not have a high school diploma. Nearly three-quarters of our patients $(73 \%)$ were married; $27 \%$ were single or divorced (Table 1).

Of the 210 patients with MS who participated in the study, $49 \%(n=103)$ were observed to use one or more AM/CM for at 
least one month and an average of 54 months (minimum: 1 month, maximum: 9.5 years). All 210 patients were found to have heard of $\mathrm{AM} / \mathrm{CM}$ treatment in $\mathrm{MS}$ after diagnosis, with $76 \%$ receiving this information over the internet, $22 \%$ from a family individual or another patient with MS, and $2 \%$ from medical staff or physicians.

Of 103 patients, $3(2.9 \%)$ were observed to reject diseasemodifying drugs (DMD) and apply these treatments for an average period of 1 year in the form of alternative treatment, the other 100 applied these treatments together with the DMD treatment in the form of complementary treatment.

Garlic, capers, flaxseed, and goat's milk in particular were more frequently used (Graph 1). One hundred patients using complementary therapy stated that they used flaxseed, capers,

\begin{tabular}{|c|c|}
\hline Patients $(n=210)$ & $\begin{array}{l}\text { Sociodemographic } \\
\text { and clinical features }\end{array}$ \\
\hline Female/male (n) (\%) & $132 / 78(62.8 \% / 37.1 \%)$ \\
\hline $\begin{array}{l}\text { Mean age (years) } \\
\text { (minimum-maximum) }\end{array}$ & $42 \pm 5.5(19-69)$ \\
\hline \multirow[t]{4}{*}{ MS type (n) (\%) } & CIS $(n=9)(4.2 \%)$ \\
\hline & RRMS (n=166) (79\%) \\
\hline & SPMS $(n=28)(13.3 \%)$ \\
\hline & PPMS $(n=7)(3.3 \%)$ \\
\hline EDSS & $3.4 \pm 2.1$ \\
\hline Mean disease duration (year) & $9.0 \pm 4.3$ \\
\hline \multirow[t]{2}{*}{ Education level (years) (n) (\%) } & $\begin{array}{l}\text { Patients without } \\
\text { high school diploma: } \\
(n=140)(66: 6 \%)\end{array}$ \\
\hline & $\begin{array}{l}\text { Patients with high } \\
\text { school diploma } \\
(\mathrm{n}=70)(33.3 \%)\end{array}$ \\
\hline \multicolumn{2}{|c|}{$\begin{array}{l}\text { MS: Multiple sclerosis, CIS: Clinically isolated syndrome, RRMS: Relapsing } \\
\text { remitting multiple sclerosis, SPMS: Secondary progressive multiple sclerosis, } \\
\text { PPMS: Primary progressive multiple sclerosis, EDSS: Expanded Disability Status } \\
\text { Scale }\end{array}$} \\
\hline
\end{tabular}

and cupping (hacamat) to treat pain/cramping, yoga, and psychotherapy to feel better physically and spiritually, and ginger, garlic, flaxseed, and goat's milk to strengthen the immune system and contribute to MS treatment (Table 2). In general, patients were largely observed to use CM primarily to relieve their symptoms. In addition, a small number of patients $(n=23)$ who were able to achieve psychotherapy were observed to indicate a benefit of over $50 \%$ in their symptoms such as pain/cramping and fatigue. Six patients argued that with flaxseed, they gained improvement in their blood tests (anaemia and liver test disorder). Patients with MS undergoing complementary treatments stated that they did not receive the response they expected from the treatments other than psychotherapy, garlic, yoga, ginger, and cupping.

Although it did not reach statistical significance, $32 \%$ of patients started using CM after their second MS attack. The average number of attacks per year was $1.8 \pm 0.2$ and no correlation was observed between the frequency of attacks of the patients and the use of AM/CM.

The average duration of disease was $9.0 \pm 4.3$ (minimum: 1 month maximum: 28) years (Table 1). Contrary to the literature, the use of CM was statistically significantly higher in those with less than 10 years' disease duration $(\mathrm{p} \leq 0.005)$. Three patients who were using more than one $\mathrm{CM}$ and also receiving first- or secondline treatments ( $\geq 1$ year's use) developed MS attacks (one optic neuritis, 2 sensory attacks). However, it was observed that the two patients who had a sensory attack had an average of 2 sensory attacks per year and that the patient who had an optic neuritis, also had an optic neuritis during the period when CM was not used.

Ninety-two patients who used one or more complementary treatments for 3 months or longer, and 107 patients who never used complementary treatments were compared in terms of MS type, sociodemographic findings, monthly income level, education level, annual number of attacks before and after using AM/CM, and EDSS scores. No association was found ( $\mathrm{p} \geq 0.05$ ). Also, there was no difference between patients receiving first- or second-line treatment in terms of using $C M(p \geq 0.05)$.

There was no statistical significance between the number of episodes of MS type, sociodemographic findings, monthly income level, education levels, monthly income levels, annual number of

\section{Complementary Therapies}

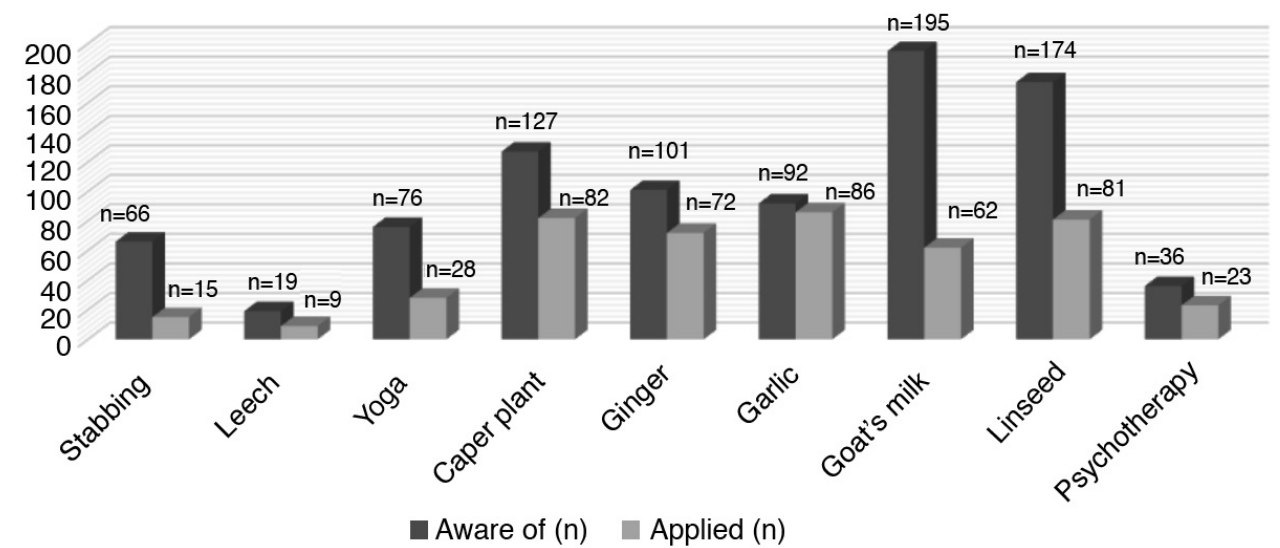

Graph 1. Most used complementary medicine treatments

*One patient used more than one complementary medicine treatment 


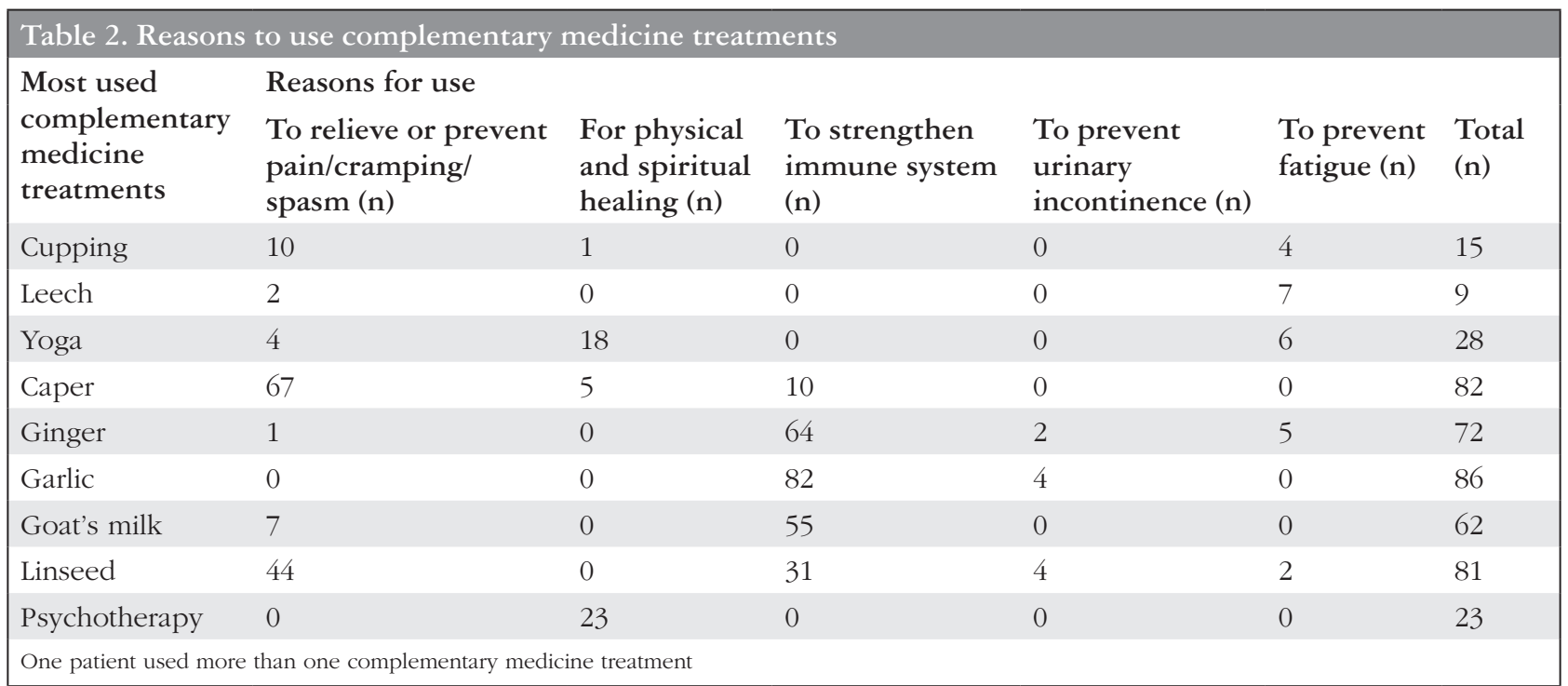

episodes before and after using AM/CM and EDSS scores of 92 patients and 107 patients who did not use them at all ( $\mathrm{p} \geq 0.05)$. No difference was also observed between $\mathrm{CM}$ use of patients with MS using first- and second-line treatment ( $\mathrm{p} \geq 0.05)$.

\section{Discussion}

In our study, in which 210 patients with MS were included, it was found that all $(100 \%)$ patients were aware of $\mathrm{AM} / \mathrm{CM}$ treatments, 103 (49\%) patients had used one or more AM/ $\mathrm{CM}$ treatments during certain periods (average 4.5 years), and the majority (100 patients) preferred these practices as complementary treatment. In a study in Germany in which 254 patients with MS participated, and in another study in America with 3140 patients with MS, $67.3 \%$ and $57.1 \%$ of patients were observed to use $\mathrm{AM} / \mathrm{CM}$, respectively $(7,8)$. Higher rates than our study were found in countries with higher levels of income and were associated with the ease of access and an excess of seeking treatment.

It was noted that the use of $\mathrm{CM}$ was expected to increase during the chronic period of the disease, the use of CM decreased as the duration of the disease became longer, more $\mathrm{CM}$ was applied in the early period of the disease, and patients preferred these treatments regardless of the duration of the disease and their disability. Those who were diagnosed as having MS newly and/or had less than 10 years of disease were found to have a statistically significantly higher level of use of one and more CM. It was also observed that all of these patients used at least one $\mathrm{CM}$ within a maximum of 3 years. This may have happened in the hope of fighting MS and recovering completely at the beginning of the disease, but as time went on it became clear that it was a chronic disease and CM use declined. In addition, although communication with the patient was shaped correctly, it was thought that patients tried these options in line with various social pressures and their quests, and then gave up with the lack of benefit. In this period, all but 3 patients maintained their medical treatment, which could be interpreted as a positive reflection of the relationship established between the patient and physician.

$\mathrm{AM} / \mathrm{CM}$ is used in different numbers and frequencies in MS as in many chronic diseases $(12,13,14)$. The frequency of AM/CM use in patients with MS was found as $25.7 \%$ by Gedizlioğlu et al. (10) in their study covering the Aegean region in 2015. In this study, which was a survey, the sources by which the patients learnt about $\mathrm{AM} / \mathrm{CM}$ were friends and relatives in $70 \%$ patients and the internet in $17 \%$. The lower rate of 'internet' as a source in the study by Gedizlioğlu et al. (10) compared with our study can be attributed to the increasing ease of access to the internet over the years. This rate was found as $46-58 \%$ in studies conducted in other countries between 2012 and $2013(2,9,10,14,15)$. The high rates of 'internet' as a source for AM/CM reported, especially in studies from North American and European countries published 5-6 years ago, may be related with the level of well-being and development of these regions. Internet access is more readily available in these countries, and the rates found in these studies are compatible with our study.

In our study, all 210 patients with MS had information about $\mathrm{AM} / \mathrm{CM}$ and 103 patients (49\%) had used or were using AM/ CM. Only 3 of 103 patients used AM/CM therapeutically, most patients preferred them in the form of complementary therapy, along with DMD treatment. This suggested that despite the pollution of information on the internet, experts' writings and information given about the disease were useful. In addition, the surveys showed that proper diagnosis, time allocation, warm behaviour, and listening to patients were important in patient satisfaction and adaptation to treatment (16). The application of this form of behaviour in our MS outpatient clinic seemed to prevent patients from going in the wrong directions in treatment.

The most commonly used AM/CM methods in patients with MS are capers, black seed oil, primrose, nettle, yoga, acupuncture, vitamins and lecithin support, and massage. Long duration of disease, increased loss of power, potential benefits to symptoms, strengthening immunity, and disease-related symptoms presenting 
at an early period are among the most common reasons for using $\mathrm{AM} / \mathrm{CM}(4,7,8,9)$.

In our study, our patients reported that they used garlic, capers, flaxseed, and goat's milk to relieve symptoms and/or to help their immune system, and that they used yoga, psychotherapy, and cupping as CM. The main causes of $\mathrm{AM} / \mathrm{CM}$ use and types of $\mathrm{AM} / \mathrm{CM}$ used in other studies in our country and in the literature were partially similar to those in our research $(4,10,11)$. Different cultural characteristics between countries can help us explain the diversity of the treatments.

In our research, which supports previous studies in Turkey and the knowledge in the literature, there was no statistically significant difference between those who applied CM and those who did not $(10,11)$ in terms of disease type, duration of disease, EDSS score, number of annual attacks, age, geographic location, and educational level. This conclusion supports the idea that AM/ $\mathrm{CM}$ is not effective on the course of the disease.

The frequency of AM/CM use was $52.7 \%$ in essential hypertension (17), $56.8 \%$ in chronic obstructive pulmonary disease (18), $48.8 \%$ in breast cancer (19), and $57 \%$ in chronic kidney failure (20). The frequency of AM/CM use in MS in our study was similar to frequencies reported in other chronic diseases.

In our study, 3 out of 103 patients with MS preferred these treatments as alternatives (AM) without using disease modifying drug (DMD) treatment, and most (97\%) patients continued the existing DMD treatment. With this result, it was clearly observed in our MS outpatient clinic that physicians could share the importance of evidence-based treatments with patients and support the treatments in the direction of scientific data.

There are currently many DMDs considered as evidencebased treatments for MS. Immunomodulatory treatments such as interferons, glatiramer acetate, teriflunomide, dimethyl fumarate, fingolimod, ocrelizumab, natalizumab, rituximab, ofatumumab, and immunosuppressive treatments such as cyclophosphamide, methotrexate, mitoxantrone, mycophenolate mofetil are included in this group. These treatments show their effects on different areas of the immune system. Regular follow-up of patients is important in terms of possible adverse effects. Complementary/ alternative treatments used with DMDs can trigger a reduction in the effectiveness of drugs and increase the occurrence of adverse effects. In our study, 3 patients had MS attacks (one optic neuritis, 2 sensory attacks) while using multiple CMs and first- or secondline DMDs ( $\geq 1$ year use). However, it was observed that 2 patients who had a sensory attack had an average of 2 sensory attacks per year, and that the patient who had an optic neuritis attack, had had an optic neuritis attack during the period when the patient did not use CM. Drug adverse effects were not observed in all 3 patients.

\section{Study Limitation}

The lack of consideration of the possible psychosocial factors (e.g. depression, anxiety) of the reasons for choosing complementary and/or alternative treatment with a psychiatrist/psychologist examination can be considered as the limitation of our study.

\section{Conclusion}

As a result, it was observed that $\mathrm{AM} / \mathrm{CM}$ was used frequently but temporarily, together with DMDs in the form of complementary therapy. In addition, contrary to expectations, it was observed that the patients preferred the use of $\mathrm{CM}$ more frequently in the early stages of the disease when their symptoms were more tolerable and their courses went relatively well. This may be due to the sociocultural pressure and desire to recover from the disease in the early period of MS. However, patients possibly then leave AM/CM due to a lack of benefit. As a result, healthcare workers should be aware of this trend, support patients with scientific/evidence-based treatments first, and bear in mind that CM can be used with MS treatments. Patients should be informed about these treatments more by physician/health staff and the importance of the patientphysician relationship in the fight against MS should not be underestimated.

\section{Ethics}

Ethics Committee Approval: Approval was obtained from the ethics committee of Istanbul Bakirkoy Prof. Dr. Mazhar Osman Mental Health and Nerve Diseases Training and Research Hospital (Decision no: 204).

Informed Consent: Written consent was obtained from all participants.

Peer-review: Externally and internally peer-reviewed.

\section{Authorship Contributions}

Surgical and Medical Practices: R.G.G.Ç., M.Ö., Concept: M.Ö., A.S., Design: M.K., M.Ö., Data Collection or Processing: R.G.G.Ç., M.T., S.A., H.S., M.K., A.S., Analysis or Interpretation: R.G.G.Ç., M.T., Literature Search: R.G.G.Ç., A.S., Writing: R.G.G.Ç., M.Ö.

Conflict of Interest: No conflict of interest was declared by the authors.

Financial Disclosure: The authors declared that this study received no financial support.

\section{References}

1. İdiman E. Multipl Skleroz Tanı ve Tedavi Klavuzu 2016. İstanbul: Galenos Yayınevi, 2016.

2. Lublin FD, Reingold SC, Cohen JA, et al. Defining the clinical course of multiple sclerosis: the 2013 revisions. Neurology 2014;83:278-286

3. Grossman P, Kappos L, Gensicke H, et al. MS quality of life, depression, and fatigue improve after mindfulness training: a randomized trial. Neurology 2010;75:1141-1149.

4. Olsen SA. A review of complementary and alternative medicine (CAM) by people with multiple sclerosis. Occup Ther Int 2009;16:57-70.

5. Oken BS, Kishiyama S, Zajdel D, et al. Randomized controlled trial of yoga and exercise in multiple sclerosis. Neurology 2004;62:2058-2064.

6. Yadav V, Bourdette D. Complementary and alternative medicine: is there a role in multiple sclerosis? Curr Neurol Neurosci Rep 2006;6:259-267.

7. Boz C. Multiple Skleroz'da Alternatif ve tamamlayıcı tedavi kullanımı. Gülümse Dergisi 2010;1:1.

8. Wiles CM, Newcombe RG, Fuller KJ, et al. Controlled randomised crossover trial of the effects of physiotherapy on mobility in chronic multiple sclerosis. J Neurol Neurosurg Psychiatry 2001;70:174-179.

9. Mews S, Zettl UK. Use of alternative and complementary therapies in clinical practice using multiple sclerosis as an example. Dtsch Med Wochenschr 2012;137:547-551.

10. Gedizlioğlu M, Yumurtaş S, Trakyalı AU, Yıldırım F, Ortan P, Köşkderelioğlu A. Multipl Sklerozda Alternatif ve Tamamlayıcı Tedavi Kullanımı: Kesitsel Bir Anket Çalışması. Turk J Neurol 2015;21;13-15.

11. Aşiret GD, Düğer Ü, Kapucu S, Kurne AT, Karabudak R. Multiple Skleroz Hastalarının Tamamlayıcı ve Alternatif Tedavi Kullanım Durumlarının 
Belirlenmesi. Gümüşhane Üniversitesi Sağlık Bilimleri Dergisi 2017;6:16.

12. Bowling AC. Complementary and alternative medicine in multiple sclerosis. Continuum (Minneap Minn) 2010;16:78-89.

13. Salamonsen A, Launso L, Kruse TE, Erikson SH. Understanding unexpected courses of multiple sclerosis among patients using complementary and alternative medicine: A travel from recipient to explorer. Int J Qual Stud Health Well-being 2010:5.

14. Stoll SS, Nieves C, Tabby DS, Schwartzman R. Use of therapies other than disease-modifying agents, including complementary and alternative medicine, by patients with multiple sclerosis: a survey study. J Am Osteopath Assoc 2012;112:22-28.

15. Skovgaard L, Nicolajsen PH, Pedersen E, Kant M, Fredrikson S, Verhoef M, Meyrowitsch DW. Use of complementary and alternative medicine among people with multiple sclerosis in the Nordic Countries. Autoimmune Dis 2012;2012:841085.
16. Skovgaard L, Nicolajsen PH, Pedersen E, et al. Differences between users and non-users of complementary and alternative medicine among people with multiple sclerosis in Denmark: a comparison of descriptive characteristics. Scand J Public Health 2013;41:492-499.

17. Güven ŞD, Muz G, Ertürk NE, Özcan A. Hipertansiyonlu Bireylerde Tamamlayici Ve Alternatif Tedavi Kullanma Durumu. Balikesir Sağlık Bilimleri Dergisi 2013;2:160-166.

18. Yılmaz CK, Aşiret GD, Çetinkaya F, Kapucu S. Kronik Obstürüktif Akciğer Hastalarının Alternatif ve Tamamlayıcı Tedavi Yöntemi Kullanımı. DEUHFED 2017;10:216-221.

19. Kurt H, Keşkek ŞÖ, Çil T, Canataroğlu A. Meme kanserli hastalarda tamamlayıc1/ alternatif tedavi kullanımı. Türk Onkoloji Dergisi 2013;28:10-15.

20. Erdoğan Z, Atik DÖ, Çınar S. Kronik Böbrek Yetmezliğinde Tamamlayıcı ve Alternatif Tıp Yöntemlerinin Kullanımı. Arşiv Kaynak Tarama Dergisi 2014;23:773-790 